\title{
11 Cinematic Dickens and uncinematic words
}

\author{
Kamilla Elliott
}

The field of novel/film studies is troubled with a central critical paradox. On the one hand, scholars declare film's integral formal, narrative, and historical connections to the novel, especially the Victorian novel. Sergei Eisenstein decrees the Dickensian novel "cinematic" (I949: I95). Christian Metz argues that film took over the social function of the Victorian novel (I977: IIO). On the other hand, scholars argue that film and the novel are inherently opposed as "words" and "images." The same Eisenstein, and most film aestheticians following him, insist that any type of verbal narration in film is "uncinematic" (Stromgren and Norden 1984: 173). Nowhere is this paradox more marked than in the claim that Dickens is "cinematic" but that words are not. What, after all, is "Dickens" apart from words? This chapter argues against both claims: that Dickens is cinematic, and that words are not.

The opening of David Lean's I946 film of Great Expectations exemplifies this paradoxical theoretical claim. The film begins with a shot of the novel, Great Expectations, opened to chapter I. John Mills, who plays the adult Pip, reads the opening paragraph in a clipped, dry voice-over: "My father's family name being Pirrip, and my christian name Philip, my infant tongue could make of both names nothing longer or more explicit than Pip. So, I called myself Pip, and came to be called Pip." The circling self-referentiality, repetition, and clutter of subordinate clauses renders the prose tedious and confusing, flowing at the speed of sound in a medium that operates at the speed of light, so that the viewer is relieved when a scouring wind rises and turns the pages rapidly in a parody of flip-book animation, which then gives way to the more sophisticated and dynamic animation processes of film. The scenes that follow are deliberately wordless, showcasing film's visual and aural vivacity. A silhouetted Pip runs pushed by a howling wind along the shoreline to a shadowy, ghoulish graveyard, where he is menaced by waving troll-like trees and creaking branches, which grasp at him like arthritic witches' arms. When we next see text from the novel, it is on the gravestone that records the deaths of Pip's parents. Unlike most films that open with shots of their 
founding text, this film does not return to show the novel closing at the end: the novel is dead and buried by the middle of the film's first scene, commemorated on the gravestone with Pip's parents. This film thus both inscribes and dematerializes the novel on which it purports to be based, in much the same way that academic criticism claims Dickens and the Victorian novel as cinematic ancestors and yet, paradoxically, denies the paternity of their words as uncinematic.

\section{Cinematic Dickens}

Montage, film historians claim, allowed film to be born as a new art rather than to be defined as a compilation of arts or, worse still, as a technological recording device for other arts (Bordwell I997: 13). Together with outdoor scenes, so the story goes, montage freed film from its designation as a flatter, less vivid, soundless, and colorless form of pictorial theater. Most important of all, scholars tell us montage created a new kind of language, a visual syntax that freed film from dependence on verbal narration. And montage, they insist, derived from scenic and visual shifts in the Victorian novel.

Even A. B. Walkley of the London Times, who in 1922 expressed skepticism regarding Griffith's claim that Dickens was his source for montage, perceives a connection between montage and the Victorian novel more generally:

Mr. Griffith found the idea to which he clung thus heroically in Dickens... he might have found the same idea almost anywhere... Newton deduced the law of gravitation from the fall of an apple; but a pear or a plum would have done just as well. The idea is merely that of a break in the narrative, a shifting of the story from one group of characters to another group. You will meet with it in Thackeray, George Eliot, Trollope, Meredith, Hardy, and, I suppose, every other Victorian novelist. (Cited in Eisenstein 1949: 205)

There are, however, several problems with this history of film and its connections to the Victorian novel.

Given its roots in photography, magic-lantern shows, public spectacles, theater, painting, tableaux vivants, and various optical toys, it is highly doubtful that film required the invisible visualities of the Victorian novel to discover its own visuality. Indeed, art historians have repeatedly and convincingly demonstrated that any visual "cinematic" propensities in Victorian novels are readily traceable to prior and contemporaneous visual and dramatic arts, arts which influenced both novel and film directly. Rhoda Flaxman has shown that, while visual description in the Victorian novel "often yields an effect we moderns call cinematic," it derives from older visual arts (I987:9-IO). Moreover, Griffith's cinematographer Billy 
Bitzer attested to drawing on Victorian paintings to create his compos:tions, with nary a mention of Dickens's prose (Gunning I 99 I: 2 50. Even. more tellingly, Dickens credits the theater for his own use of "montage"

It is the custom on the stage, in all good murderous melodramas, to present the tragic and the comic scenes, in as regular alternation, as the layers of red and white in a side of streaky bacon... sudden shiftings of the scene, and rapid changes of time and place, are not only sanctioned in books by long usage, but are by many considered as the great art of authorship. (I966: 168-9)

When one considers that Griffith was both playwright and stage actor before he turned to film, it is improbable that the technique filtered through to him directly from the novel without any influence from theater.

Why, then, do both film and literary critics continue to press the Dickens/cinema analogy and the primacy of the novel/film link over film's debts to other arts, like painting and theater? Both mythologies thrive, Jespite considerable contradictory evidence, because they serve each side ff the literature/film rivalry. On the literary side, designating Dickens in zarticular and the Victorian novel more generally the immediate ancesors of film forges a history of narrative that creates a continuous line trom oral poetry through the rise of the drama and subsequently the rise novel through to film and television. Such a lineage gives the literary : amp film credits, positioning literary scholars as experts credentialed to $\because$ iscuss films as well as written texts, and to do so using literary methAs, methods that tend to favor literature over film whenever they are $\therefore$ scussed in conjunction with each other.

And yet this anachronistic analogy has not been overthrown by film - Adies, because it also supports film's bid for cultural and representa$\because$ nal dominance. The myth of the cinematic novel, intriguingly, asserts -at film grew out of the Victorian novel - though not from its words :--A not from its illustrations. Such an argument creates a mythical virgin -..-th for film, in which film derives only invisible visualities and immate- structures from the novel. Were film to acknowledge its debt to the - el's actual words and illustrations, or to other arts, like painting and :eater, its birth would appear far more mundanely derivative. The film : mp represents the partially cinematic novel as an incomplete precursor

: the purely cinematic film, establishing a hierarchy in which any film -.mps any novel, since all films are more "cinematic" than even the most $\therefore$-. matic fiction. The anachronism of the cinematic Victorian novel thus - ies film the glorious fulfillment of what is only a seed of promise in - . novel, rather than representing itself as the feeble offspring of a more - : nnt narrative parent. The literary camp does not counter this aspect of $=-$ ilmic myth, because parenting film makes Dickens modern and even 
timeless. It bestows on him seminal and prescient powers that allow him to be read not only as our contemporary, but as ahead of his own time, prophetic rather than antiquated, eccentric, or sentimentally nostalgic.

\section{Uncinematic words}

The move to denigrate words as uncinematic and, as far as possible, to rid cinema of them has been important to establishing the myth of film's virgin birth from the novel. By and large, film aestheticians and historians have tended to see language of any kind in film as hampering and competing with film's language of montage, an indication of filmic immaturity or filmmaker ineptitude, a reluctant concession to narrative necessity, a contamination of the pure art of film by literature. I want to question the claim that words are uncinematic through a consideration of intertitles (also called title cards, subtitles, leaders, and captions) in so-called 'silent' film adaptations of Dickens's novels. While my readings are limited to these adaptations, they do have more general applications to a considerable body of Anglo-American (melo)dramatic films made in the same period.

Purists from the earliest days of film to the present have perceived the pinnacle of filmic representation as one entirely free from verbal language. James Card rhapsodizes over "silent films so eloquent in their pantomime that they needed no intertitles whatsoever - no dialogue, no explanatory titles, just pure, uninterrupted images. What a boon to international distribution - no language barrier anywhere!" (I994: 60). Ralph Stephenson and J. R. Debrix assert, "In silent cinema, the written captions were always an alien element and never combined with the visuals into an artistic whole" (1978: 207). This sense that intertitles comprised a contamination of film by literature was strong during the silent period. In I928, the Ukrainian theorist Leonid Skrypnyk complained, "Cinema has to humiliate itself and seek compromises. Intertitles constitute the first major compromise" (20). A reviewer in 1929 referred to intertitles as "literary hemorrhages" (Milne I929: IOI). Intertitles, the argument runs, were a temporary crutch, a compromise with literature, while film fumbled toward its manifest destiny, its own "visual" language, the editing between shots that could create a purely visual narrative and syntax apart from words. In this argument we see that not only does montage free film from theater, but also from the written word of the novel.

Film historians argue unilaterally that, the more film developed its visual language, the less it required and used verbal intertitles. The evidence, however, overwhelmingly contradicts this claim. While some early and late silent films do indeed manage without intertitles and, while there 
$\therefore$ a temporary reduction in the length of intertitles between the early silent zriod (before I908) and the middle silent period (I908-I7), in the late $\therefore$ int period (I9I8-26), when the celebrated visual "language" (editing) $\therefore$ irmly established, in the vast majority of films, intertitles are far more =-olix and appear much more frequently than before film "language"

:av root. Bafflingly, film historians do not contest these facts: those who ¿Aress intertitles do confirm that they grew more verbose and frequent; $\therefore$ ey simply ignore the critical paradox.

Dickensian adaptations provide succinct illustrations of the more $\Xi=n e r a l$ phenomenon that intertitles grew longer and more frequent. $\because$ :agraph's I9I I $A$ Tale of Two Cities uses between eleven and twelve in$\therefore$ :titles per reel of film; the later 1926 adaptation of the novel (titled The

mly Way, after the I 899 stage version) bears an unusually high number, $\div$ : n for this period - thirty-five per reel. Since many cards are narrative -.:les and not just stage dialogue, the higher number cannot be explained :mply as the result of adapting a play. Moreover, length as well as frezinency increases in the late silent period: the curt cards of the I9I I $A$ zic of Two Cities give way to florid and verbose cards in the 1926 version. Fr example, I9II's "The first stain of the revolution" becomes I926's And whilst St. Antoine danced the Carmagnole, never did the moon -: - with a milder radiance on a quiet corner in Soho"; I9II's "To the E-illotine" elongates to 1926's "In the black prison of the Conciergerie, $\therefore$ a doomed awaited their call to the Guillotine." Another pair of mid䀡 late-period silent films adapting the same Dickensian novel show : $m$ ilar tendencies: the I9I2 Thomas Bentley Oliver Twist bears between seren and eight intertitles per reel, while the 1922 First National version zarries eighteen per reel. Again, the cards are not only more frequent, ¿dt also more loquacious. I9I2's "Rose saves Oliver, who is adopted by Mrs. Maylie," becomes "Bill's murderous purpose was thwarted by the Providence of a just God and Oliver quickly recovered from the slight sound in his shoulder." (Intertitles often vary from print to print in the slent era. I have seen other versions of intertitles for this film: here, I cite ine intertitles from the British Film Institute's copy.)

Not only does the argument that film "language" decreased the need cor intertitles in late silent films fail to hold for a majority of films, the : Jea that film editing is a purely visual language is also contradicted by a closer look at intertitles in late silent films. The very word, intertitles, suggests intercutting; indeed, some of the first editing practices were bewreen intertitles and single-shot scenes. The earliest film in which I have cound intertitles (two years earlier than any other film scholar to date has .ocated) is W. R. Booth's I9o I Scrooge, Or Marley's Ghost. The first extant intertitle reads: 
Scene II

Marley's Ghost

Shows Scrooge Visions of himself in

CHRISTMASES PAST.

It is followed by two vignettes, one of a woman and boy together and or: of a young man kissing a girl, representing somewhat obscurely Scrooge rescue from boarding school by his sister and his broken engagemen: The film continues to alternate cards and scenes: thus between words and scenes lie some of the earliest origins of film editing.

This kind of editing has been overlooked, I believe, not only becaus of the low status of language in film aesthetics, but also because editin between intertitles and filmed scenes points to montage practices base in verbal language rather than freed from it. To set the stage for this argument, a brief consideration of mid-silent titular practices (1908-17) is in order. In this period, intertitles continue to function as scene heading: or verbal explications of filmed scenes, increasingly appearing only to represent what images could not specify or what would require too many: images to delineate. This becomes clear when we look at Vitagraph: I9I I $A$ Tale of Two Cities. Intertitles append names to faces and, within that naming, state the legal relations of characters ("Doctor Manette, his servant Defarge, and his infant daughter, Lucie"). Similarly, words make spaces places ("In England"; "In Paris") and specify passages of narrative time ("Eighteen years after the events of Part I"). They represent words spoken by silently moving mouths ("Take this estate for the benefit of the people"); convey the silent thoughts and plots of characters ("The Marquis, now hating Darnay, sends a criminal to London to accuse him of being a spy"); explain the significance of a scene ("Darnay acquitted", or an absence from a scene ("The Marquis" companion fails to appear") Titles pull the general from specific images ("The starving populace"); provide an adjectival narrative tone ("An ominous summons"; "A joyful reunion"); and offer moral commentary on an action ("The aftermath of the crime. The wrecked home").

But this rigid division of narrative labor between intertitles and filmed scenes led increasingly to complaints of narrative disruption, resulting in new intertitular practices in the late silent period aimed to ease the transitions between intertitles and filmed scenes. As one writer in I92 I put it:

Picturegoers of to-day who can recall the early days of the kinema industry will retain memories of the crude and ugly explanatory sub-titles that once disfigured the silver sheet. In those days the sub-title was regarded as a necessary blemish on the face of the film, and no attempt was made towards either literary or artistic improvement. (Anon. 192I: 2I) 
During this period, intertitles were illustrated to ease the transition beween pictures and words, and texts (like letters) were legible in the scenes. Dialogue cards increased in proportion to narrative cards, so that sords would appear to come from the scenes rather than from an omnisient narrator. But for my argument here, the most relevant effort made $\therefore$ remedy disjunctions lies in changing editing practices between interti$\therefore$ es and filmed scenes. Far from film language replacing verbal language $i$ the late silent period, there develops a complex interweaving of interti$\therefore$ es and scene shots to form hybrid verbal-visual "sentences." In Maurice Elvey's I920 film of Bleak House, a scene shot between two intertitles is -ot simply an illustration of the words but part of a complex visual-verbal ミntence:

$\therefore$ IERTITLE But the third morning of the elopement brings bad news...

ot of a distraught Captain Rawdon holding a letter; close-up of the letter's text revealing his disinheritance

$\therefore$ IERTITLE ... and the sheriff's officer tracks Rawdon and executes his warrant.

- Te narrative here is primarily verbal, using the text of the letter to expli:zte the intertitle's "bad news." But the shots between the intertitles also -.ustrate and dramatize the character's reaction to the news, so that the - srrative import is by no means entirely conveyed by words. More imztantly, for all the rhetoric addressing the visual and musical rhythms : montage, in these sentences the montage is guided primarily by verbal mtax.

Frequently in the latter part of the late silent period, intertitles carry less $\therefore$ the narrative and create more purely rhetorical and rhythmic effects. - :e last two intertitles of the 1924 Little Dorrit contain only dependent $\therefore$ zuses, between which are sandwiched shots of Little Dorrit's wedding Arthur Clennam: "Beyond the sombre shadow of the Marshalsea..." --d "And that was one hundred years ago." The shot of the wedding -.us forms the main "clause" of the "sentence"; words state only a zue place and distant time and have a primarily rhetorical and emotive $=\ddot{z} \mathrm{ct}$.

In some cases, incomplete sentences begun by intertitles are completed $\because$ pictures alone. When Dot asks John where he found the Old Man in the $: 23$ film of The Cricket on the Hearth, we see a shot of John replying, but $\because$ : intertitles represent his words. Instead, the scene fades to black and ?ns on a new outdoor scene depicting John's discovery and conveyance $\therefore$ he Old Man. An intertitle concludes only: "- and he slept all the way $=-2, "$

These rhetorical rhythms are not limited to dialogue cards, but extend narrative cards as well. Omitting actor credits for Manette and Defarge 
that appear on two of the cards, The Only Way contains a sequence that runs:

INTERTITLE Then, sixteen years...

Long shot of the Marquis and guests feasting

IN TERTITLE ... Years that to Evremonde recorded only the passing of Time

Midshot of the Marquis and guests

INTERTITLE Years that so changed another, that even, freed from the Bastille.

the twilight of his mind held him prisoner

Midshot of Manette holding a shoe and staring vacantly at camera

Long shot of a concerned Defarge, Lorry, and Lucie standing near Manette

INTERTITLE Years that burned the hatred of a decadent aristocracy into one

having reason to hate

Midshot of Defarge speaking

At a time when most intertitles are end-stopped, the absence of punctuation at the end of these cards positions the shots more particularly as punctuation. The semantic and syntactic relationships of the sequence are thus established by the run-on sentence of the intertitles, rather than by narrative relationships between images (looker and looked-at, actor and reactor). Here intertitles function as rhetorical pacers, adding the emphasis and force of dramatic pauses. In this way, images come to take on aural properties as well as visual ones. But again, the shots do not have purely aural and rhetorical functions: they also illustrate the words, even empirically "proving" their hypotheses.

The evidence that Dickens is not cinematic and that words are, even in that bastion of cinematicity, montage, is clearly overwhelming. Yet the two interdependent mythologies persist regardless, because both literary and film camps use them to foster interdisciplinary rivalries and word/image rivalries within film itself. The evidence of these hybrid titling practices points to new ways in which Victorian novels and films, as well as the words and pictures within films, can be explored, indicating that, far from destroying a fruitful connection between Dickens and the screen. putting to rest the myths of cinematic Dickens and uncinematic words will open rather than close down paths for analysis.

\section{REFERENCES}

\section{Books}

Anon. I92I. "The Art of the Sub-Title." The Picturegoer May: 2 I.

Bordwell, David. 1997. On the History of Film Style. Cambridge, MA: Harvard University Press.

Card, James. I994. Seductive Cinema: The Art of Silent Film. New York: Knopf. Dickens, Charles. 1966. Oliver Twist. Harmondsworth: Penguin. Originally published I $837-9$.
E:szstein, Sergei. I949. "Dizkz=s,

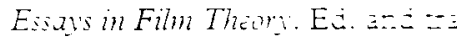
is World, Inc. I95-25:.

\#.rman, Rhoda L. I98-. I............. $\because g$ of Genres. Ann Arbor. M.

-roing, Tom. I991. D. W. G........

Lrbana: University of Ill:m: $\therefore$ ב. Christian. 1977. The $I \cdots, \cdots=$

Trans. Celia Britton, Aras Bloomington: Indiana $L=\ldots, \ldots$ $\therefore$ e. Peter, 1929. No title. Pi..... anah, Julian. I98I, "See:Noiel and the Mories. Eis. . . Frederick Ungar. $143-54$.

:-anyk, Leonid. I928. 12 . . : : : ryd.

$\therefore-\div$ henson, Ralph and J. R. DE: Penguin.

:-mgren, Richard L. and Ma:...

Englewood Cliffs, NJ: Prea....

Films

$\therefore:$ Scrooge: Or, Marley's Gr... D. -:. A Tale of Two Cities. D:Vitagraph. USA.

$\because: 2$. Oliver Truist. Dir. Thoma: BE:-:

_:3. Scrooge. Dir. Leedham Bart?

ニニ. Bleak House. Dir. Mauric E

-za. Oliver Twist. Dir. Frank L :

-23. The Cricket on the Heart: D:Pictures. USA.

-23. David Copperfield. Dir. A. W - +. Little Dorrit. Dir. A. W. SE: -25. The Only Way. Dir. Herke::

-5. Great Expectations. Dir. D

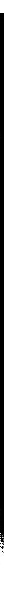


E: :enstein, Sergei. I949. "Dickens, Griffith, and the Film Today." Film Firm:

Essays in Film Theory. Ed. and trans. Jay Leyda. New York: Harcourt, Brace \& World, Inc. 195-255.

Fxman, Rhoda L. 1987. Victorian Word-Painting and Narrative: Toward the Blending of Genres. Ann Arbor, MI: UMI Research Press.

Y...nning, Tom. 1991. D. W. Griffith and the Origins of American Narrative Film. Urbana: University of Illinois Press.

i:-Z. Christian. 1977. The Imaginary Signifier: Psychoanalysis and the Cinema.

Trans. Celia Britton, Annwyl Williams, Ben Brewster, and Alfred Guzzetti.

Bloomington: Indiana University Press.

- 2 , Peter. 1929. No title. Photoplay. Jan.: Ior.

ahan, Julian. I981. "Seeing the Book, Reading the Movie." The English

Novel and the Movies. Eds. Michael Klein and Gillian Parker. New York:

Frederick Ungar. I43-54.

any, Leonid. 1928. Narysyz teorii mystetstva kino. Kiev, Ukraine: Derzhavne $\because$ id.

- =-2inson, Ralph and J. R. Debrix. 1978. The Cinema as Art. Harmondsworth: Penguin.

.... gren, Richard L. and Martin F. Norden. 1984. Movies: A Language in Light.

Englewood Cliffs, NJ: Prentice-Hall.

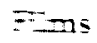

: : Srooge: Or, Marley's Ghost. Dir. W. R. Booth. R. W. Paul. UK.

$\therefore$-A Tale of Two Cities. Dir. William Humphrey and Stuart J. Blackton.

$\because$ :agraph. USA.

- = hier Twist. Dir. Thomas Bentley. Hepworth Films. UK.

. : Srooge. Dir. Leedham Bantock. Zenith Films. UK.

.: Bicak House. Dir. Maurice Elvey. Ideal Films. UK.

.: Tier Twist. Dir. Frank Lloyd. First National. USA.

. "7e Cricket on the Hearth. Dir. Lorimer Johnston. Biograph/Paul Gerson artures. USA.

$\therefore$ D Jiid Copperfield. Dir. A. W. Sandberg. Nordisk Films. Denmark.

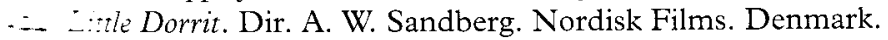

$\therefore \quad$ Only Way. Dir. Herbert Wilcox. UK.

-.. Sat Expectations. Dir. David Lean. Cineguild. UK. 